\title{
An Assessment of Employees Performance Management in Selected Local Governments of Ogun State
}

\author{
Olukemi Aluko $\mathrm{PhD}^{1 *} \quad$ Mbada Kike $\mathrm{PhD}^{2}$ \\ 1.Department of Local Government Studies, Obafemi Awolowo, Ile-ife, Nigeria \\ 2.Department of Political Science, Obafemi Awolowo University, Ile-Ife
}

\begin{abstract}
This paper examines the implementation of performance management of employees in two Local Governments Areas of Ogun State, Nigeria with a view to assessing its successes, challenges and implication on public service delivery. The paper adopted content analysis as a way of gathering data, in total, 30 respondents comprising of heads of departments and middle level employees were purposively sampled. The data gathered from the interviews were analysed using Miles and Huberman's (1994) approach to qualitative data analysis. The findings revealed that the managers had good understanding of the purpose and implementation of performance management, but the implementation has not been effective. The reasons for this ineffective implementation range from lack of uniform process in the system, varying performance management indicators, poor monitoring and evaluation, to godfatherism, dearth of funds and lackadaisical attitude of workers to work. This paper concludes that, unless and until, employee performance management is effectively implemented in Local Governments in Nigeria, effective public service delivery would remain a travesty of grassroot development.
\end{abstract}

Keywords: Performance management, local government administration, globalization and development

DOI: $10.7176 /$ PPAR/10-9-08

Publication date:September $30^{\text {th }} 2020$

\section{Introduction}

Essentially, employee performance management is considered a process of building a work atmosphere that stimulates and support people to perform to the best of their capacities and capabilities. It is a medium through which administrators conveys what is expected from employees and give feedback on how good they are performing and reaching their job goals. It brings together many of the elements that make up the practice of people management, including, in particular, learning and development (CIPD, 2009).

Performance management establishes shared understanding of what is to be achieved and provides an approach to leading and developing people that will ensure it is achieved; as such it is an essential element of your role and will support your relationship with individuals in your team.

In the last 25 years performance management has been the siren's song for nations around the world (Ingraham; 2005); governments across the globe are implementing various reforms at the four key areas of performance in any managerial level in identified by Lebas in the public sector. Labas (1995) argued that; personnel performance, individual performance, team performance and organizational performance form the bedrock of assessing performance of an organization and it is on these four areas that management of performance can be realized. The need for the call for performance management in the public sector is founded on the realization of the effects of globalization vis a vis advancement in technology enhancing the movement of people for a better life. Also, the needs of these people are subject to how governments respond and supply such needs; for instance, many people depend on the government for waste disposal, maintenance of roads, provision of basics health care facilities; thus, making government object of criticism from citizens and other stakeholders where such works were not performed. The criticism is usually higher in the local governments due to the fact that this is the government closest to the people. In this regard, managers in the public sectors need to understand what motivates individuals in different cultures and context in a bid to achieve the goals of the institution or organisation.

Aguinis (2005) argued that a continuous process of identifying, measuring and developing the performance of individuals and teams and aligning with the strategic goals of the organization can result to performance of such organizations. This implies that the success of any organisation either private or public; the local government inclusive equates to successful performance management system that will include individuals and teams in line with the targets given to them within a stipulated time frame. For instance; in United States of America, performance management in the local governments includes setting clear and specific performance expectations for each employee and providing periodic informal and/or formal feedback about employee performance relative to those stated goals (https://www.shrm.org). Japan's performance management in the local governments includes: assessment of employees in the form of a meeting with, and written feedback from, the immediate superior every six months. In addition, Japan uses performance-related pay (PRP) in the form of one-off bonuses and/or permanent pay increments. The performance-related component of pay can vary pay levels within grades between $8 \%$ and $80 \%$. (https://www.oecd.org/gov/pem/OECD).

In Nigeria Performance management in the public sector dates back to the Udoji's panel recommendation; but inspite of various public reforms at ensuring performance of employees in local governments; many people 
are of the opinion that the local governments are not performing to their expectations. Many scholars Adeyemo (1999), Aransi (2010), Aborisade (1997), Ola (1991) and Olowu (1994) in the field of local government studies in Nigeria have attributed corruption, political interference, paucity of funds as well as lack of professionals as challenges to performance measurement and management mainly from organizational perspective of performance. The paucity in Literature on performance management of individuals and teams in need of building their capacities must be addressed because of the impact of the employees in driving the vehicle for the attainment and fulfillment of organizational goals.

This paper focuses on the local managerial staff regarding the purpose and implementation of performance management of employees and its challenges with a view of accessing performance management in local governments in Ogun State, using two local governments (Owode and Abeokuta South Local Governments) as case study. The first section is the introduction; the second section is the theoretical framework, while the third section is literature. Methodology is the fourth section with findings as the concluding section.

\section{Literature Review \\ Performance Management}

Performance management systems are embedded in the doctrines of traditional Weberian public administration which includes specialization, decentralization, reward for workers and productivity. Performance management has been used for years in the local governments to review and evaluate performance of the workers in accordance to the goals and objectives of the institution.

The term Performance management is defined as doing all that is required to continuously improve performance of every employee in relation to his/her role, dyad, team and the entire organization in the context of the short and long term goals of the organization (Rao, 2016). The State of Oklahoma Training and Development manual states that performance management is a communication process by which managers and employees work together to plan, monitor and review an employee's work objectives and overall contribution to the organization. Walters (3) shares the same view when he defined performance management as the process of directing and supporting employees to work as effectively and efficiently as possible in line with the needs of the organisation.

The definitions clearly show that performance management is different from performance appraisal and that it involves good communication, cooperation, setting of achievable goals/tasks, monitoring system, reward for achieving the goals and also development of employees.

Furthermore, Armstrong (2006); argued that performance management must be a systematic process and it must be for improving organizational performance by developing the performance of individuals and teams. He further explained that performance management is both a strategic and integrated approach to delivering sustained success to organisations by improving the performance of the people who work in them and by developing the capabilities of teams and individual contributors in the organisation. Rao (2016) shares the same view with Armstrong but emphasized that continuously improving performance of every employee in relation to his/her role, team and the entire organization in the context of the short and long term goals of the organization can foster performance.

In addition, Agocs (2005), Briscoe and Claus ( 2008), clearly stated that Performance management must be characterized by seven processes namely: there should be a system through which organizations set work goals, secondly, there must be standards to determine performance, work must be assigned and evaluated, provision for performance feedbacks, determine training and development needs of employees and distribute reward fairly. Armstrong (2006) opined that five elements of performance management are: (1) identify standards, goals, or desired level of performance; (2) measure performance; (3) communicate performance; (4) compare performance information to desired standard; (5) take action to close any gap between desired standard and actual performance should be the foundation of any system and processes involved in performance management.

Wouter et al (2010) identified eight movements that led to the development of performance management; which he classified into three time segments or series namely: Pre-World War II, 1950s to 1970s and 1980s upward. The World War II witnessed three movements based on events, the first was the social survey movement which was targeted at addressing social inequalities that was affecting the poor working class. Van Dooren, Bouckaert and Halligan (2015) further argued that social survey movement focused more on why workers were poor in an organization and aimed to know how poverty can be alleviated so as to boost production. The second movement was the scientific movement and science of management which was to address how government work can be conducted without promoting corruption, ensuring that resources from industrial revolution was adequately managed for the provision of infrastructures, through the employment of professionals at all levels of government. The third movement, cost accounting, deals with the management, tracking and analysing cost associated with government finance. The 1950 s and 1970 s, time frame ushered performance budgeting including management by objectives and zero-based budgeting into performance management. The last time frame 1980s upward conceives new public management and evidence based policy.

The aims of performance management which includes empowering, motivating and rewarding employees 
and aligning everyone's individual goals to the goals of the organization, should propel initiatives to improved performance with an emphasis on increased efficiency, effectiveness of service delivery and improved accountability to the public. While these aims make sense and the performance management approaches are generally well intended, many organizations in the public sector seem to approach performance management with an emphasis on collecting and reporting data that produces little insights, learning or improvement (Van Dooren, Bouckaert and Halligan, 2015).

Having all of the elements of the performance management cycle in place is very important. But this will not necessarily lead to effective performance management for your organisation. There are many other factors in play, such as:

- Having buy-in from leadership and senior management to performance management

- Ensuring the performance management cycle is continuous and not an annual process

- Ensuring performance conversations and reviews are meaningful and not"tick-box" exercises

- Having easy to use performance management software which supports effective performance management and gives you visibility of performance management activity.

- The skills and willingness of your managers to deliver effective performance management on a day-today basis

\section{Performance Management in the Local Governments in Nigeria}

In Nigeria, there are seven hundred and seventy four local governments warped within the thirty six states of the country. Local governments are recognized as the third tier of government with their function in both the executive and residual lists of the 1999 Constitution of Federal Republic of Nigeria (As Amended). In section II 7(3) states that "it shall be the duty of a local government council within the State to participate in economic planning and development of the area referred to in subsection (2) of this section and to this end an economic planning board shall be established by a Law enacted by the House of Assembly of the State." The fourth schedule further stated the other functions as:

(a) the consideration and the making of recommendations to State commission on economic planning or any similar body on - (i) the economic development of the State, particularly in so far as the areas of authority of the council and of the State are affected, and

(ii) proposals made by the said commission or body;

(b) Collection of rates, radio and television licenses;

(c) establishment and maintenance of cemeteries, burial grounds and homes for the destitute or infirm;

(d) Licensing of bicycles, trucks (other than mechanically propelled trucks), canoes, wheel barrows and carts;

(e) Establishment, maintenance and regulation of slaughter houses, slaughter slabs, markets, motor parks and public conveniences;

(f) construction and maintenance of roads, streets, street lightings, drains and other public highways, parks, gardens, open spaces, or such public facilities as may be prescribed from time to time by the House of Assembly of a State;

(g) naming of roads and streets and numbering of houses;

(h) provision and maintenance of public conveniences, sewage and refuse disposal;

(i) registration of all births, deaths and marriages;

(j) assessment of privately owned houses or tenements for the purpose of levying such rates as may be prescribed by the House of Assembly of a State; and

(k) control and regulation of -

(i) out-door advertising and hoarding,

(ii) movement and keeping of pets of all description,

(iii) shops and kiosks,

(iv) restaurants, bakeries and other places for sale of food to the public,

(v) laundries, and

(vi) licensing, regulation and control of the sale of liquor.

2. The functions of a local government council shall include participation of such council in the governing a state in respects of the following matters -

(a) the provision and maintenance of primary, adult and vocational education;

(b) the development of agriculture and natural resources, other than the exploitation of materials

(c) the provision and maintenance of health services; and (d) such other functions as may be conferred on a local government council by the House of Assembly of the State.

The performance management of each of the local governments centers on these functions and each state government assembly is to direct the activities of these local governments through the passage of laws and bills that will enhance performance. Unfortunately, the major focus is on organizational performance management with little attention to employee performance management which is achievable though the local government service 
commission that trains workers from time to time. This is the core of performance because managers depend on the people to drive and deliver the goals and objectives of any organisation.

\section{Methodology}

This paper adopted content analysis and relied on primary study source of data. Two local governments in Ogun State namely: Owode and Abeokuta Local Governments were purposely selected due to their sizes. The study population included Heads of Departments, Directors, and managerial level of the selected local governments, totalling 40. The research relied on structured interview questions and the interviewees were randomly selected in each of the departments because they were in charge of implementing the performance management strategies and techniques in the institutions. Content analysis was used to analyse the results collected from the field.

\section{Findings:}

\section{Interview Analysis}

This section comprises qualitative analysis of data collected from in-depth interviews conducted among selected stakeholders in Ogun State on performance management implementation within the Owode and Abeokuta South Local Government Administrative Systems. The interviewees were given opportunity to provide open and diverse information on what Local government as an organization does, its missions and responsibilities. They were also interrogated on their understanding of performance management implementation, its strategic, operational and individual levels as well as the outcome of performance management implementation within the local administrative system in Ogun State.

Majority of interviewees acknowledged variety of what local government, as an organization, can do towards discharging civic duties. One of the cardinal stances of local government is "to provide social services for the populace." Holistically, a Senior officer in Owode Local Government remarked that "local government, as an organization, is designed to bring governance to people at the grassroots level." This is an indication that governance at the local level has no recourse; governance is the rationale behind the establishment of local government which all of its functions must center around. It is however emphasized that it (Local government) is structured to "move government closer to the people and to create employment for the youth."

More inclusively, the role of local government is of numerous concerns which encompasses health, agriculture, education, administration and general services needed in the localities. This assertion was buttressed by the various quotations of the interviewees: On the health perspective, it was said that "local government performs environmental health activities i.e which is controlling those factors in our physical environment which may have a deleterious effect on the physical, mental and social wellbeing of people." Simply put, on agricultural stance, sensitization, mobilization and training of farmers remain operational task of local government, as evident in Owode and Abeokuta South Local Government Areas of Ogun State.

A community development officer in Owode noted that "the action lines of local government are to meet the yearning of citizenry through provision of essential social services as well as its maintenance." Thus, the assertion underlines the social perspective. It was further argued that the functionality of the local government relies on the generation of internal revenue. This therefore explicates the general services via the promotion of community development activities and environmental management. Remarkably in Abeokuta South, the strength of local government, as an organization, was re-affirmed via provision of social services and amenities; creating awareness among people on governance. Hence, local government serves as an 'enabler' for democracy. It was clear that the respondents interviewed had a clear understanding of the goals and the aims of local government in the state. They all agreed that local governments were to provide essential social services in health, environment, agriculture, education and general services as stipulated in the 1999 Constitution of Federal Republic of Nigeria (As Amended).

Having clarified the status quo of local government in Ogun State using Owode and Abeokuta South Local Government Areas, this section further inquired into the understanding and usability of the concept of performance implementation management. Most interviewees explained that performance management is 'central or core key to an organization.' This position is an underlined submission made by senior careerists in Abeokuta South and Owode Local Government Areas in Ogun State. It was observed from the content of interviewees' discourse that "performance management is a process by which managers and employers work together to plan, monitor and review employees' work objectives."

However, a Director of Personnel Management in Owode Local Government Area noted that "as efficient as performance management in an organization, its full operationalization has not been enhanced, though on average basis, consequent upon non-availability of funds." It could be inferred that performance management is an operational role of government and management team at the local level aimed at enhancing attainment of goals, employee satisfaction and development agenda. 'What performance management implementation portends' was however clarified by the interviewees. A common ground was reached on inclusiveness as its key process. Also, a senior administrative officer stressed that "...the implementation goal of performance is to promote and improve employee effectiveness to the discharge of his/her duties." 
In furtherance, employee effectiveness is not an absolute end. It was hinted by a Director of Personnel Management in Abeokuta South Local Government Area that "implementation of performance management is not independently for employees to be effective, rather it is the subsequent result of their effectiveness that will bring about staff productivity with progressive indices on deliverable social services." Amongst others, the interviewees in the Abeokuta South and Owode Local Government Areas reflected on, and believe that, optimum productivity, regular consultation, changing employees 'orientation, setting targets, and organizational task consistency are the identified aims of performance management implementation in Ogun State Local Government Service.

In addition, an enquiry was made on the kinds of processes used for performance management in Ogun State Local Government system. A top official in Abeokuta South Local Government narrated that "it involves a number of processes which include planning, monitoring, assessment and review; sometimes, punctuality and honesty can serve as informal yardsticks for management of performances." A senior careerist in Owode Local Government Area explained that "evaluation processes can be designed and re-designed at periodic intervals with the motive of managing the performances of respective employees at various cadres." Also, monitoring of activities, gathering information, workforce planning, evaluation and assessment were re-affirmed to the most processes used in the performance management implementation. This negates the process involved in performance management as identified by Armstrong (2002), Agocs (2005), Briscoe and Claus( 2008), employees don't have access to performance feedback hence, areas of training and development according to needs cannot be determined clearly. Secondly, the process is not a continuous exercise and this is more like performance appraisal.

With the understanding of the kinds of processes involved in performance management implementation, an investigation was therefore made on those who are partakers in the processes. A cross-section of the interviewees enlisted those who are involved to be top management officers, the management staff of the organization (Local Government), the executive arm of government, the heads of local government administration and directors of various departments, Director in Local Government Service Commission, all the managerial staff including all employees at the planning stage, as well as political and career officers. This means that other staff are not included. Performance management involves all employees at all cadre because when it involves the managerial levels only, it becomes performance appraisal.

A careful information was then sought on the resources needed to manage performance among employees in the Local Government Service within Ogun State. Majority of the interviewees in Abeokuta South and Owode Local Government Areas identified common factors to include: funds, manpower and necessary machineries, human and financial resources, as well as professionalism. The usefulness of resources could be acknowledged in provision of necessary working tools, critical and analytical statistical data collected during monitoring exercise, Annual Performance Evaluation Reports (APER), team work and regular verification of the job done to ascertain compliance, as well as review of the performance level of each project.

Having analysed the procedural processes, resources needed and working elements of performance management implementation, it was then put straight to the interviewees whether the performance management has been an effective implementation tool. Descriptively, thirty seven (37) out of every forty (40) interviewees accredited the assertion that the implementation of performance management has enjoyed considerable level of compliance within the local government service in Ogun State. Although, there are reservations as to the level of effectiveness.

According to a director in Owode Local Government Area, while acknowledging the efficacy of performance management, it was reserved that "jobs are implemented in line with organization's strategies such that its goal is effectively accomplished." Remarkably, it was stressed by a senior careerist in Abeokuta South Local Government that "it has been an effective implementation but without discussion, meeting and monthly report ... one may not know if there is a great achievement." An assertion was made by one of the interviewees also in Abeokuta South Local Government Area that "it is commonly noted to be a guide to job performance." Similarly, a succinct statement was put forth by Director of Personnel in Abeokuta South Local Government that "it shows the progress made and the effectiveness of the goal set,... and more advantageously, it instils the spirit of commitment in individual employee to meeting up with target set for him/her."

On the issue of performance management data, its availability was acknowledged by most of the interviewees in Abeokuta South and Owode Local Government Areas. Also, the usage of performance management data was unanimously said to be coordinated by the executive, the heads of departments and overall head, top management team, and the Local Government Service Commission in the State. The visibility of performance management data was widely acknowledged, but one of the interviewees in Abeokuta South noted that "it is most times made visible consequent upon its request by the individual staff, staff unions, committees within the local government system and Local Government Service Commission at the State level.

A categorical question was asked in respect to usable criteria for evaluation of performance within the Local Government Service in Ogun State. The following factors were reeled out by most of the interviewees in Abeokuta South and Owode Local Government Areas, such as: monitoring, through the use of suggestion box by subordinate, target setting, evaluation report, extent of job done compared to target set, and Project Evaluation and Review 


\section{Technique (PERT).}

From the foregoing, this study tends to confirm whether those criteria are crystals linked to the performance management system in Ogun State, using Abeokuta South and Owode Local Government Areas. To a very large extent, the positions of interviewees appear acknowledging the ordinate linkage between the used criteria and performance management system owing to its non-secrecy. The practicability of synergy between the criteria and performance management system are said to be exhibited in a form on periodic basis, thereby accumulating to individual staff promotion at three (3) years intervals.

Also, the sufficiency of training and development opportunities offered and supported by top management was rated to be regular with little limitations. As observed from the interview response, the limitations vary from one individual to another. However, a common feature of the limitations is the political influence that was mostly submitted by interviewees in both Abeokuta South and Owode Local Government. By political influence, it means that most staff members, who enjoy training and development opportunities are those who have affiliations with political office-holders, 'straight partners' of directors or with their trade/labour union executive, example, National Union of Local Government Employees (NULGE).

The managers using performance management revealed that collective achievement, up-to-date data for evaluation, boosting better performance of worker, improvement and positive increase in productivity, ability to formulate policy decision, ability to provide legal documentation, identification of shortcomings of staff members, and proper discharge of duties within the time frame are the major constraints faced by performance management. However, the main weaknesses of the performance management implementation are paucity of funds, nonavailability of other required resources, weak performance management indicators, non-availability of performance management information and preferential treatment.

A polar question was asked i.e whether the implementation of the performance management system has assisted in the achievement of the agreed performance targets. There was a remarkable level of positive acknowledgement (Yes) in the interview response. Therefore, a follow-up question was put forth on how the implementation of performance management system has been of help. This has been so helpful, according to a careerist in Owode Local Government Area, because "No one has a pinnacle of knowledge, everyone needs to upgrade him/herself, everyone needs to change... (sic)." A Director of Personnel Management in Abeokuta South extolled the usefulness of the implementation of performance management system that "it is a form of providing opportunities for staff industrial training as well as on-the-job training," ... and it was buttressed that "the result will determine the next step to take to improve in the discharge of responsibility." Generally, it spared staff members to improve commitment to duty.

On the implementation outcomes, this study found that the implementation of performance management system has, in a broad term, enhanced development, growth and progress of the Local Government Service system in Ogun State. Put simply,' it gives room for better services and achieving goals of the organization through general staff commitment. Sometimes," it has helped in the area of detecting and abating nuisance'. More notably, 'the implementation of performance management system has resulted in increment of Internally Generated Revenue (IGR) of the local government system in Ogun State owing to target setting system of their revenue collection units and 'raised awareness of communities on government programme'.

\section{Conclusion}

The study revealed that performance management system has all-inclusive values as a managerial tool in the Local Government system as highlighted by the respondents, though the implementation of performance appraisal is taken as implementation of performance management among employees. Thus, the strengths of the performance management identified in the study are not much because few managers use it personally to get result and it is not a continuous process.

The findings and conclusions of the study indicated that certain constraints affect the effective implementation of the performance management system by the Ugu district municipality and these include, among other things, the role of oversight structures which is not exercised, the lack of monitoring and evaluation of performance, the lack of alignment of performance review outcomes with personal development plans, and inability to utilise the performance management system to improve services that are delivered to the community.

\section{References}

1. Amended Constitution of the Federal Republic of Nigeria (1999). The National Industrial Court. Lagos: The Federal Government Printer

2. Bouckaert G, Halligan J (2008) Managing performance: international comparisons. Routledge, London

3. Boyne G (2010) Performance management: does it work? In: Walker RM, Boyne GA, Brewer GA (eds) Public management and performance: research directions. Cambridge University Press, New York

4. Tanaka H (2009) Evaluation in local government in Japan. Council of Local Authorities for International Relations (CLAIR), Tokyo 